\title{
New uses for old infrastructure: 101 things to do with the 'stuff' next to the hole in the ground
}

\author{
SJ Finucane Bioscope Environmental Consulting Pty Ltd, Australia \\ K Tarnowy Bioscope Environmental Consulting Pty Ltd, Australia
}

\begin{abstract}
Ten years ago, the Post-Mining Alliance in association with the Eden Project published Georgina Pearman's 101 Things to Do with a Hole in the Ground. This publication illustrates the ways in which closed mines have been repurposed in an environmentally, socially and economically sustainable manner. However, there was limited mention of repurposing the associated mine infrastructure. This is understandable given that the focus of the tome was on the 'hole in the ground', and in fact illustrates how much companies prioritise planning for closure of open pits and underground workings, along with other large mine features such as waste rock landforms and tailings storage facilities. Indeed, mining companies commonly propose only to decommission mine support infrastructure and dispose of it onsite or elsewhere. However, repurposing of mine infrastructure can also provide significant value.

Recent research has identified numerous ways in which mine infrastructure (such as railway lines and processing plants) and other commodities (such as conveyor belting and vehicle tyres) can be repurposed and provide benefit for the environment and community. It is clear from this research that the way in which mine infrastructure can be re-used or repurposed varies from site to site, and requires consideration of a range of factors including the location and type of infrastructure, landscape ecology and landscape architecture, the regional and local planning context, regulatory frameworks and economics. In some instances, these initiatives go beyond adaptive re-use to become landscape architectural projects that are more about invention than merely corrective measures of rehabilitation or restoration.

This paper discusses new ways to use old mine site infrastructure. It presents case studies on repurposing infrastructure from a number of countries, and identifies key success factors and limitations for these projects. The way in which these aspects affect decision-making associated with post-mining use of infrastructure is also discussed. The paper concludes that a long-term vision and a business case (and, in some instances, also legislative change and even a marketing plan) are critical to allow appropriately timed and cost-effective custodial transfer of infrastructure assets.
\end{abstract}

Keywords: infrastructure closure, adaptive repurposing, industrial archaeology

\section{Introduction}

When considering options for post-operational use of mines, most mining companies focus on the potential offered by open pits and underground workings, waste rock landforms, mineral processing facilities and tailings storage facilities. For example, in 101 Things to Do with a Hole in the Ground, Pearman (2009) showcases a range of post-mining land uses including entertainment and leisure, sport, food and drink, medicine and therapy, energy, habitat, science and technology, mining heritage and energy; in No Longer Just a Hole in the Ground, McCandless (2013) lists around 20 uses simply for former quarries such as hotels and adventure parks; while in a paper on sustainable post-mining land use, Kivinen (2017) discusses the use of 51 former metals mines for a range of uses including agriculture, forestry, recreation and conservation. However, despite extensive literature on post-mining land use options, there tends to be limited discussion on repurposing infrastructure associated with a mine. This is despite the fact that former mining infrastructure can be re-used or repurposed in myriad ways that provide environmental, community and economic benefits. 
In essence, mine site infrastructure can be classified into two categories: infrastructure required to develop and operate the mine, and infrastructure needed to transport ore or a beneficiated product to the processing site, port or market (Anon 2014). Mining companies invest significantly in developing and maintaining this infrastructure, and indeed it has been stated that:

"Mining companies live and die by mine site infrastructure. It's the backbone to any successful operation and has the ability to either enhance productivity or harm it." (Anon 2014)

What is interesting is that, despite significant investment in infrastructure, most mining companies propose only to decommission and dispose of it onsite or elsewhere during mine closure. This happens for a range of reasons including the cost of transporting the item to another location compared to the cost of decommissioning and disposal onsite (particularly where transportation costs exceed the purchase value of the item), tenure restrictions, legal constraints and long-term warranty and liability issues. However, there are numerous ways in which mine infrastructure (such as railways and processing plants) and commodities (such as conveyor belting and vehicle tyres) can be repurposed and provide benefit beyond the life of a mine. Therefore, 10 years after the 101 Things to Do with a Hole in the Ground was published (Pearman 2009), it is timely to discuss 101 things to do with the 'stuff' next to the hole in the ground.

\section{$2 \quad$ Places and spaces}

Recent research has identified numerous ways in which mine infrastructure, such as railway lines and processing plants, and materials, such as conveyor belting and vehicle tyres, can be repurposed. One hundred and one examples are listed in the Appendix, with selected examples discussed in Sections 2.12.7. These include sites from six of the world's seven continents (Africa, Asia, Europe, North America, South America and Australia). In some instances, these initiatives go beyond adaptive re-use to become landscape architectural projects that are more about invention and innovation than merely corrective measures of rehabilitation (Corner 1997; Loures \& Panagopoulos 2007).

While not every example listed in the Appendix is for infrastructure from a mine site, all of these illustrate the way in which materials and items utilised on mine sites can provide additional benefit for the environment and community long after the mining and mineral processing operations for which they were originally utilised have closed. The most popular uses for mine infrastructure were community and business infrastructure, tourism and recreation (including heritage trains and museums).

\subsection{Tourism and recreation}

In a place best known for its connections to the Wild Wild West, an old gold processing plant has been repurposed not once but twice. In 1874, the discovery of gold in the southern Black Hills of South Dakota set off one of the great American gold rushes. Two years later, miners moved into the northern Black Hills to discover a gulch full of dead trees and a creek full of gold, and Deadwood was born (Anon 2019a). Practically overnight, the tiny gold camp became a boom town that attracted not only miners looking for fortune but also outlaws, gunslingers and gamblers. The town was frequented by legends such as Wild Bill Hickok (who was gunned down while playing poker just a few weeks after arriving in Deadwood), Calamity Jane, Seth Bullock and Potato Creek Johnny (Anon 2019a).

Initially, mining gold at Deadwood Gulch was simple, with miners merely washing the gold dust and nuggets from the gravel creek beds. However, these workings were soon exhausted and it became necessary to use more sophisticated forms of hard rock mining (Anon 2018). This led to the establishment of a slime plant that used a process developed by CW Merrill to extract gold from slime (a byproduct of crushed ore suspended in water) (Anon 2019a). The plant operated from 1906 until 1973, after which Lawrence County turned part of the building into a heavy-equipment maintenance shop that served the community for a number of years. In 2001-2002, extensive environmental clean-up was conducted on the portion of the property still owned by Homestake Mining Company (Duex 2010). Consequently, the slime plant was repurposed for a second time to become the Deadwood Mountain Grand hotel and casino 
complex. Façade restoration was funded by the city's Historic Preservation Commission who helped the Deadwood Mountain Grand's partners preserve and honour Deadwood's historic mining heritage (Anon 2018).

Coincidentally, around the same time that work commenced on the second of the Deadwood slime plant conversions, Benguet Corporation was prompted to restructure its operations in the Philippines and consolidate its resources in response to a turbulent business climate. It broadened its businesses beyond mineral exploration and mining to include ecotourism and other interests, and converted its mining facilities in Balatoc into what the company promoted as the Benguet Mines Tourism Village. The company also advertised other facilities at the mine for out-of-town functions (Chaloping-March 2008). Mine infrastructure has also been repurposed for ecotourism at the San Martin mine in Honduras (Roldan \& Purvance 2011).

Repurposing former mine infrastructure for tourism and recreation accounts for around $25 \%$ of the uses listed in the Appendix. If examples of re-use in heritage trails and museums (see Section 2.2) are included in this total due to their role in tourism and recreation, it increases to nearly $40 \%$. Repurposing of railways and railway corridors for tourism and recreational pursuits is particularly popular (see the Appendix), as is re-using them as part of heritage trails (see Section 2.2 and the Appendix). It is noted that there are opportunities to combine railway tourism with other forms of tourism such as indigenous tourism and ecotourism.

\subsection{Heritage trails and museums}

Mining equipment and mine support infrastructure are popular inclusions in mining museums and heritage trails (see the Appendix). These feature strongly in areas where there is a long history of mining including the Cornish Mining World Heritage Site (www.nationaltrust.org.uk) and the Northeastern Goldfields of Western Australia (www.gwalia.org.au). Many of these museums and trails showcase large infrastructure such as winders, pumping stations, boilers, dredgers and engines (McNab 2018; National Mining Museum Scotland 2019; www.nationaltrust.org.uk; www.gwalia.org.au), but even small items such as tools and workers' possessions attract tourists to the Geevor Tin Mine Museum and Heritage Centre in England (McNab 2018) and the Wieliczka Salt Mine Tourist Route in Poland (Pearman 2009).

Provision of heritage railway attractions, including railways associated with mining and mineral processing operations, is considered to be an important component of railway tourism (Lee \& Chen 2016). Further, the idea of 'rails to trails' has been implemented successfully around the world. For example, marketing for the Flokkefjordbanen railbiking path in Norway uses the slogan "cultural salvation through active use", with local residents intent on preserving the railroad and turning it into a living museum (Batten 2018).

\subsection{Exercise facilities and sporting venues}

In the same way that mine pits can be an 'attractive nuisance' after closure (Parshley \& MacCallum 2016), mining infrastructure can attract visitors keen to see and explore, and even climb, old processing plants and other structures (see the Appendix). However, repurposing former mine infrastructure for exercise and sporting pursuits is not common, with around $10 \%$ of the examples cited in the Appendix accounting for this type of re-use. This is possibly because these features can be dangerous if not made safe. However, if they can be converted safely to exercise facilities and sporting venues, they allow members of the community to indulge in their fascination for 'industrial archaeology' without harm (Townsend 1992). Further, the transformation of derelict industrial facilities, such as former processing plants, into public spaces significantly enhances quality of life and land use (Loures \& Panagopoulos 2007) and brings "a new perspective to disused machinery and redundant sites, celebrating local history and a sense of place" (Pearman 2009).

Duisburg-Nord Landscape Park in Germany provides a number of examples of how an abandoned site can be reclaimed without eliminating the memory contained in the landscape (Loures \& Panagopoulos 2007; Rademeyer \& Le Roux 2008). Through provision of a climbing garden, a highwire facility and the biggest 
artificial diving centre in Europe, the park allows people to enjoy "the pleasure of ruins" (Macaulay 1953) or the pleasure associated with exploring physical remains of the past (Lowry 2001).

Opportunities to exercise and challenge oneself to go to greater heights are also available at Ferropolis, a former coal mine that now hosts a 25,000-seat concert venue and offers the opportunity to climb or abseil down one of the other "sleeping giants" at the site (Pearman 2009). Those who prefer less-challenging forms of exercise can explore the walking paths developed at the Homestake Mine's mill and refinery (Duex 2010) and community greenways such as Canada's Trans-Canada Trail or the Cowichan Valley Regional Trail on Vancouver Island (Backhouse 2012). Community greenways not only encourage activities such as walking, cycling on paths and off-road and horse riding but also integrate mine sites and working landscapes to "acknowledge the importance of resource extraction activities and incorporate these requirements within a comprehensive plan for sustained environmental and recreational networks" (Backhouse 2012).

Another popular pursuit is railbiking, where specialised bikes are mounted on railway tracks no longer used to transport ore and other goods. For example, the Adirondack Railbiking Path allows tourists access to areas of the Adirondack Mountains previously mined for iron ore and titanium dioxide (Anderson 2017). For those more interested in aquatic pursuits, the Zollverein Colliery in Germany now hosts a swimming pool and ice rink for community use (Pearman 2009).

\subsection{Native fauna habitats}

There are several examples of sites where former infrastructure has been used to create native fauna habitats, although this is the least common of the post-operational uses for mine infrastructure identified during preparation of this paper, accounting for less than $5 \%$ of the uses listed in the Appendix. Most of those listed relate to construction of artificial reefs and marine habitat. For example, an old locomotive has been used to form an artificial reef in the Red Sea (Preuss 2010), and a collection of retired subway cars donated to the Delaware Department of Fishery have been lowered into the ocean just off the Delaware coast to create fish habitat. Known as the Redbird Reef in honour of the New York subway trains used to form this artificial reef, the cars now provide a habitat for blue mussels, worms, crabs and shrimp that provide a food source for reef fish (Jochum \& Witkop 2010).

Further examples of constructing artificial reefs include the Rigs to Reefs program. This program is gaining momentum across coastal states in the United States of America (USA) as an alternative to decommissioning old oil rigs (Recfishwest 2017), with an eight-leg rig having the ability to provide up to three acres of habitat for marine life, which can support 12,000 to 14,000 fish. However, before being considered suitable for use as fauna habitat, the rigs have to pass strict environmental and structural standards (Bureau of Safety and Environmental Enforcement n.d.).

Our final example of repurposing former infrastructure marine habitat construction is the Parker Point Artificial Reef near Dampier in Western Australia. The reef was constructed from more than 10,000 tonnes of reconstituted concrete from conveyor foundations and boulders from a decommissioned seawall. During 10 years of environmental monitoring, the artificial reef has been observed as growing at a rate of $30-40 \%$ greater than natural reefs (Zhou 2018).

These examples demonstrate that it is possible to use old mining infrastructure for fauna habitat (particularly in the marine environment), although there are questions regarding the suitability of certain materials for this purpose (see Section 3.5).

\subsection{Fisheries and agriculture}

It is not often that the words 'organic' and 'mining' are used in the same sentence, but there are a number of sites where mining and industrial infrastructure has been converted to organic food production facilities. The examples provided in the Appendix account for around $10 \%$ of the uses reviewed during preparation of this paper. For example, the Vryheid Coronation Colliery in South Africa was repurposed as an organic food 
processing plant (Pearman 2009) and an abandoned train turntable in Finland has been rejuvenated as an organic food hub (Burnham 2018). The re-use of railway infrastructure can also be seen at the Oden State Fish Hatchery in the USA, which includes an old railway car that now houses a major fish rearing facility (Preuss 2010).

Used conveyor belting has myriad uses including nonslip flooring for livestock (Spiegel 2013), cattle windbreaks and barriers (Atlas Belting n.d.), and as mats for animal pens (Atlas Belting n.d.). Further, tyres and drums from mine sites can be repurposed as livestock feeders, and water pipelines can be re-used not only as farm pipelines but also as livestock fencing (Spiegel 2013).

\subsection{Community and business infrastructure}

Repurposing for community and business purposes is perhaps one of the more likely uses of former mining infrastructure. As for tourism and recreation, it accounts for around $25 \%$ of the uses listed in the Appendix. Opportunities for community and business use are more likely to exist where mines occur in close proximity to settlements and larger population centres.

Former mining infrastructure has been repurposed for residential, office, hotel and retail facilities in a range of countries. These include Indonesia, where it was agreed during stakeholder engagement that camp buildings at the Kelian mine would be donated to the local government for use by the community (McGuire 2003); Canada, where buildings from the Gaspe mine were donated to the town of Murdochville (Gauthier 2013); the Democratic Republic of Congo, where former accommodation facilities present an opportunity for re-use as a training and conference centre (Limpitlaw \& Briel 2014); and demountable buildings from the Tom Price iron ore mine repurposed as clubrooms at the Tom Price Horse and Pony Club. A number of those who design libraries seem to have also been inspired to re-use mining and industrial infrastructure and commodities. For example, a former powerplant in Austin now houses a library (Barber 2017) and reclaimed railway sleepers were used for library extensions in Spain (Mairs 2015).

From our review, it appears that retired trains and train stations are often converted into eateries, hotel facilities, information centres, training centres and even churches (fairbanksalaskabedandbreakfast.com; Francis \& Salveson n.d.; Pasquini 2009; Preuss 2010). They can also be used to provide accommodation and other facilities for the homeless (Burnham 2018; Chow 2008).

In some instances, former mine infrastructure continues to be used for its original purpose, but no longer in the mining industry. For example, a hydroelectric plant in South Dakota continues to provide power, but is now owned by the City of Spearfish and is used to provide electricity to the local market instead of the mine (Duex 2010). Further, a reverse osmosis water treatment plant used previously to treat polluted water from an underground coal mine in South Africa now provides potable water to a local municipality (Pearman 2009).

\subsection{The arts}

Former mining and industrial infrastructure seems to be a popular choice for art studios and creative spaces. For example, a former steel yard on the Woonasquatucket River in Providence is now a community and gathering space for the arts (Barber 2017), the Village Underground in East London includes retired railway carriages and old containers that now form a creative cultural hub that hosts live art, concerts, theatre and other activities (www.villageunderground.co.uk), and a gallery has been established in a former dry goods store in Kentucky (Barber 2017). Further, railway sleepers form part of an art centre extension in Utah (Frearson 2012).

Many artists are repurposing mining infrastructure and commodities like scrap steel and using these to create works of art. Artists working with these materials include Arizona-based artist John V Wilhelm, who uses railway spikes, scrap metal and other items to create outdoor items (Metal Men Recycling 2015), and Sir Anthony Caro, whose Babylon sculpture features used railway sleepers (Jesus College 2019). In Durham, colliery scrap metal was used to create the head of the King Coal sculpture (Pearman 2009). 


\section{$3 \quad$ Influencing factors}

In his keynote address at Mine Closure 2016, Adjunct Professor Bruce Harvey stated that:

"Companies, communities and regulators faced with mine closure scenarios should explicitly place future economic occupation of mine sites at the forefront of mine closure visioning and leave open future options for creative human enterprise." (Harvey 2016)

Certainly, many of the examples cited in this paper are the result of human creativity and imagination. However, it is not always possible or wise to repurpose mine structures for other uses following mine closure. There may be many obstacles that the proponent will need to consider and incorporate into planning to effectively repurpose infrastructure, along with many opportunities. A number of questions are asked below in relation to factors that can influence decision-making related to re-using former mine infrastructure.

\subsection{What are our options?}

Not all infrastructure from every mine site can be repurposed. Often the environmental, financial and other costs of deconstruction, transportation and reconstruction of infrastructure in a new location (or repurposing in its existing location) outweigh the potential benefits of re-using these items. On this basis, the first step in planning the re-use or repurposing of mine infrastructure is to identify future use options in conjunction with government, community and other stakeholders.

One of the main influencing factors is whether there is a demand or market for the infrastructure that could be made available once it is no longer needed for mining and mineral processing. After all, there are only so many buildings that can be re-used as community halls and only so many railway lines that will hold value for a community. It also appears from our review that the distance between the repurposed infrastructure and settlements is a strong influencer, along with cost (see Section 3.3). Proximity to population centres is important where mine infrastructure is proposed for redevelopment as community and/or business facilities, as people usually prefer to minimise the time that it takes to travel to these facilities, and the viability of these facilities often depends heavily on their level of use. Consequently, mine infrastructure repurposed as community or business facilities needs to be convenient to access. In contrast, being distant from a settlement can be viewed positively by those who want to get 'off the beaten track'. In these cases, mining heritage trails and recreational facilities are likely to be more attractive to vacationers if located in more remote areas.

Companies may need to monitor or get involved in local and/or regional planning to identify opportunities for future use and position assets to maximise these opportunities. They will then need to conduct costbenefit analyses to identify a shortlist of options. Scoping, pre-feasibility and feasibility studies could then be conducted, resulting in the development of a business case for the preferred future use option. It is important to ensure that adequate time is allowed for all of the engineering, geotechnical, economic, environmental and community investigations required to support these studies and develop the business case.

In addition to feasibility studies, a marketing plan may be required, particularly if the infrastructure in question is to be transferred to a third party who may not initially see merit in the opportunity and may be reluctant to become involved. The most effective way to obtain support from potential future custodians is to involve them to the maximum practicable extent in planning for repurposing of the infrastructure in question.

\subsection{Is repurposing allowed under the relevant regulatory framework?}

Regulations and legislation can strongly influence the ability of the proponent to repurpose infrastructure. Often, a mine's environmental approvals and/or mine closure plan require that the proponent remove all infrastructure from the site as part of its decommissioning and closure work program, so new or additional approvals will be required if former mine infrastructure is to be re-used or repurposed. In some instances, 
changes to legislation and/or regulations may also be necessary, particularly if project-specific legislation has been enacted. For example, in Western Australia, legislation known as State Agreement Acts form the legal contract between the state government and the proponent of certain major development projects. State Agreements define the rights, obligations, terms and conditions relevant to development of that project (Department of Jobs, Tourism, Science and Innovation n.d.), and may provide direction or instruction in relation to decommissioning and closure of the project. If the proponent wishes to implement an alternative plan, changes to that legislation will be required as its provisions can only be changed through agreement between the government and the proponent.

The ability to repurpose mine infrastructure in Western Australia is also constrained by land use legislation, which limits land use transitions under the Land Administration Act 1997 (Government of Western Australia 1997). In response, the Western Australian Government introduced the Land Administration Act Amendment Bill 2016 (Government of Western 2016), which should provide a regulatory pathway for aligning mine closure with regional development (Murphy 2016).

Other issues that need to be considered in relation to the regulatory framework include whether any residual environmental or other liability will remain with the former landholder following site closure, or if this liability can be transferred to the new landholder or other party such as the government. For example, in South Australia, the Environment Protection Act 1993 (Government of South Australia 1993) provides for the transfer of liability for site contamination, in part or in full, under certain circumstances defined in the Act (Environment Protection Authority 2010). Similarly, in Western Australia, the Contaminated Sites Act 2003 (Government of Western Australia 2003) allows for responsibility for remediation of a contaminated site to be transferred to another party with that party's written agreement and the written approval of the Minister for the Environment. However, the minister will only approve transfer of liability where he or she is satisfied that the transferee has sufficient financial capacity to carry out the remediation (Moulis Legal 2015).

\subsection{Is repurposing economic?}

It is now a standard requirement for mining companies to prepare closure cost estimates for their open pits and underground workings, waste rock landforms, mineral processing facilities and tailings storage facilities, and mine support infrastructure (see, for example, Department of Mines and Petroleum and Environmental Protection Authority 2015). However, from our review it appears that there is little or no published information on the actual cost of repurposing mine infrastructure, let alone comparing the cost of closing mine infrastructure to the cost of re-using or repurposing these facilities. Consequently, it is difficult to comment on the economic opportunities and constraints associated with repurposing former mine infrastructure. However, it seems unlikely that the cost of deconstruction, transportation and reconstruction of infrastructure in a new location would be less than the cost of onsite decommissioning and disposal of infrastructure for many mines, particularly those in remote areas. On this basis, it is reasonable to assume that those mining companies in this situation that choose to repurpose former mine infrastructure do so for reasons other than economic ones.

If a proponent has agreed that mine infrastructure will be transferred to another party, it needs to ensure that this occurs expediently as facilities that are not moved in a timely manner may deteriorate over time, potentially making future repurposing more expensive and potentially more risky from engineering, environmental, community, health and safety, and other perspectives. Consequently, it is recommended that a schedule be developed for custodial transfer of the assets to occur within a time frame that minimises the risk of reduced asset viability and increased costs. Further, it is recommended that the mining company investigate whether the new owner has the financial and other capabilities to manage and maintain the facilities for which it is taking custody, and reviews this situation regularly. Alternative arrangements may need to be made if the new owner does not have adequate capacity to take custody of the infrastructure at the time at which this transfer is due to occur. 


\subsection{Is there a need for development partners?}

In recent years, the term 'partnership' has been used in relation to a wide range of relationships. Increasingly, mining companies are developing partnerships with governments, indigenous communities, non-government organisations and other stakeholders to seek shared value not only during mining operations but also following closure of the mine.

In the context of this paper, 'partnerships' are defined as arrangements where all parties have a common goal, objective or strategic interest; are transparent; share information and conduct joint fact-finding; pool funds or in-kind resources; utilise the core and complementary competencies of each of the parties; and share the financial, reputational and other risks and benefits associated with the venture (Finucane 2016). Each of the parties that participate in the partnership brings a different set of values, priorities, resources and competencies; the challenge therefore is to bring these diverse contributions together under a common vision in order to achieve the agreed goals of the partnership (The Partnering Initiative 2019).

The need for development partners for repurposing mining infrastructure is gaining greater recognition. For example, several projects that would be beneficial for the mining, tourism and economic industries of the Pilbara region of Western Australia are being developed with thought being given to multiple potential future users of mining infrastructure (Pilbara Development Commission n.d.). According to the Town of Port Hedland's Chief Executive Officer David Pentz:

"Continuing improvements in economic infrastructure, particularly in regards to Pilbara ports and the potential repurposing of mining and energy sector infrastructure, is pivotal to the continued growth of the Pilbara." (Pilbara Development Commission n.d.)

Mining companies choose to partner with other organisations because they cannot achieve their desired goals by other, non-partnership means. While it is essential for partners to share a common goal and to agree on desired outcomes, it is also important that the individual partners recognise and accept that each of the partner organisations has the right to expect benefits that will be specific to them. Indeed, partnering agreements often reflect the right of each partner to achieve specific goals as well as common goals. Consequently, it is important to ensure that any specific goals are acceptable to the other partners and that they are not in conflict with the shared goal of the partnership (The Partnering Initiative 2019).

\subsection{Is the infrastructure fit for purpose?}

The structural integrity and materials used, as well as the location, size and shape of the infrastructure all contribute to the suitability of that infrastructure for an alternative purpose. In the case of artificial reefs, mining infrastructure such as oil rigs, cement foundations and rubble have all been used as construction materials. These 'materials of opportunity' (or ' $\mathrm{MOO}^{\prime}$ ) are a cheaper alternative to purpose-built reefs, although they are usually a less preferred option due to the risk of adverse environmental impacts such as heavy metal leaching and asbestos, low stability during severe weather events and associated remediation costs. These materials need to be adequately cleaned and modified for purpose and are required to comply with strict environmental regulations, otherwise they would not be considered fit for purpose (Recfishwest 2017).

Mining infrastructure is usually constructed for immediate use, with little or no consideration for aesthetic use or values, resulting in utilitarian and visually unappealing structures. Structures that are considered to be unattractive may have limited potential for re-use post-closure, but if opportunity for repurposing is recognised during mine planning, then buildings and other infrastructure can be designed with that use in mind (Rademeyer \& Le Roux 2008).

\subsection{What will the influence be on closure planning?}

It is important that companies are cognisant that some of the future uses for mining infrastructure could change their mine closure strategies and government or other approvals related to these. This is particularly the case if an opportunity to repurpose mine infrastructure arises after a site's mine closure 
plan has been approved. Accommodating this change may require modification to closure objectives and completion criteria, closure implementation and monitoring programs, closure cost estimates, etc. It is also likely that additional stakeholder engagement will be required.

In addition to the above, there is a need for landscape design strategies to be included in mine closure planning. Loures \& Panagopoulos (2007) note that landscape reclamation design needs a clear vision and strategy and should apply collaborative design principles. It needs to protect and conserve quality (natural or man-made) landscapes and needs to enhance biodiversity, social sustainability and economic development. Finally, it needs to ensure that adequate resources are allowed for long-term aftercare.

\subsection{What legacy does the proponent want to leave?}

Repurposing mine infrastructure provides a unique opportunity for the proponent to support communities that rely on the mine to survive and thrive post-closure. Over its life, a mine may become the primary source of income and services for local communities, and in this way, the mine develops a social responsibility for the future of these communities. Repurposing infrastructure has the ability to establish alternative economic opportunities and strengthen local livelihoods and food security (Bainton \& Holcombe 2018).

The Homestake Slime Plant in Deadwood, South Dakota, was renovated into a casino and resort (Anon 2019a), while the accommodation camp, maintenance shop and administration offices at the San Martin mine in Honduras were repurposed to form an eco-hotel (Roldan \& Purvance 2011). Both these examples provided opportunities for the local communities to develop tourism as an alternative local economy to reduce reliance on the mine.

Infrastructure can also continue to provide services such as power and clean water post-closure. The Homestake Mining Company transferred ownership of a hydroelectric plant to the City of Spearfish, South Dakota; the Vryheid Coronation Colliery in South Africa converted its power supply and machinery into an organic vegetables processing plant; and a desalination plant for treating polluted water in an underground coal mine in Witbank, South Africa, now provides drinking water for a local community. Though the mines have closed, their infrastructure still provides essential services allowing the local communities to survive.

\section{Conclusion}

Progressively, more companies are identifying opportunities to repurpose mine infrastructure and are taking action in this regard. In addition, there is increased government and community recognition of the environmental, social and economic benefits associated with these opportunities. However, the way in which mine infrastructure can be re-used or repurposed varies from site to site and requires consideration of a wide range of factors including the location and type of infrastructure, landscape ecology and landscape architecture, the regional and local planning context, regulatory frameworks, environmental considerations, stakeholder requirements and economics. It is concluded that a long-term vision and a business case (and, in some instances, also a marketing plan) are critical to allow appropriately timed and cost-effective custodial transfer of infrastructure assets.

\section{Acknowledgement}

The authors wish to thank Justin Fromm (Pilbara Development Commission) for his input to this paper. We also thank those who reviewed the draft of this paper for their constructive comments. 


\section{Appendix: 101 uses for former mining, mineral processing, transport and support infrastructure}

\begin{tabular}{|c|c|c|}
\hline Uses & & Description \\
\hline \multicolumn{3}{|c|}{ Processing plants, power plants and associated infrastructure } \\
\hline 1 & $\begin{array}{l}\text { The Works Swimming } \\
\text { Pool, Essen, Germany }\end{array}$ & $\begin{array}{l}\text { The Works Swimming Pool is located within the coking plant at the Zollverein Colliery in } \\
\text { Germany and is considered to be "both a work of art and a popular leisure area" } \\
\text { (Pearman 2009). }\end{array}$ \\
\hline 2 & $\begin{array}{l}\text { Heavy-equipment } \\
\text { maintenance shop, } \\
\text { Deadwood, USA }\end{array}$ & $\begin{array}{l}\text { After the Homestake Slime Plant shut down, Lawrence County converted part of the } \\
\text { building into a heavy-equipment maintenance shop (Anon 2018). }\end{array}$ \\
\hline 3 & $\begin{array}{l}\text { Deadwood Mountain } \\
\text { Grand hotel and casino, } \\
\text { USA }\end{array}$ & $\begin{array}{l}\text { The Homestake Slime Plant is now a hotel, casino, restaurant and entertainment venue in } \\
\text { South Dakota (Anon 2019a). }\end{array}$ \\
\hline 4 & $\begin{array}{l}\text { Multi-use complex, } \\
\text { Austin, USA }\end{array}$ & $\begin{array}{l}\text { Residential, office, hotel and retail facilities, as well as a library and restaurants, are } \\
\text { located in a former powerplant in the Seaholm District of Texas (Barber 2017). }\end{array}$ \\
\hline 5 & $\begin{array}{l}\text { Concrete Plant Park, New } \\
\text { York City, USA }\end{array}$ & $\begin{array}{l}\text { An abandoned concrete plant has been converted into a public park where visitors can } \\
\text { see the former concrete equipment alongside a waterfront promenade, bike paths and } \\
\text { chess tables (Barber 2017). }\end{array}$ \\
\hline 6 & $\begin{array}{l}\text { Climbing Garden, } \\
\text { Duisburg-Nord, Germany }\end{array}$ & $\begin{array}{l}\text { A climbing garden in Landschaftspark has been established in blast-furnace bunkers } \\
\text { previously used to store coke and ore (Loures \& Panagopoulos 2007; Pearman 2009). }\end{array}$ \\
\hline 7 & $\begin{array}{l}\text { High Wire, Duisburg- } \\
\text { Nord, Germany }\end{array}$ & $\begin{array}{l}\text { The former iron and steelworks now house a series of paths, swaying bridges and rope } \\
\text { structures for the adventurous (Loures \& Panagopoulos 2007; Pearman 2009). }\end{array}$ \\
\hline 8 & $\begin{array}{l}\text { Goat Farm Arts Centre, } \\
\text { Atlanta, USA }\end{array}$ & $\begin{array}{l}\text { Industrial buildings now house exhibition halls, a café, creative studios for artists, an } \\
\text { education centre and an organic farm (Barber 2017). }\end{array}$ \\
\hline 9 & $\begin{array}{l}\text { Organic Vegetables } \\
\text { Processing Plant, South } \\
\text { Africa }\end{array}$ & $\begin{array}{l}\text { The Vryheid Coronation Colliery (a former coking coal site) along with its power supply } \\
\text { and machinery has been converted into a food processing plant that exports organically } \\
\text { grown beans to North America and Europe (Pearman 2009). }\end{array}$ \\
\hline 10 & $\begin{array}{l}\text { Seattle Gas Works Park, } \\
\text { Seattle, USA }\end{array}$ & $\begin{array}{l}\text { A former gasification plant was converted into a public park in 1975. Much of the old } \\
\text { plant remains, with the plant's former exhauster-compressor building repurposed as a } \\
\text { children's play barn (Barber 2017). }\end{array}$ \\
\hline 11 & $\begin{array}{l}\text { Tauchgasometer, } \\
\text { Duisburg-Nord, Germany }\end{array}$ & $\begin{array}{l}\text { A disused gas holder among decommissioned metalworks at Landschaftspark provides } \\
\text { the biggest artificial diving centre in Europe (Loures \& Panagopoulos 2007; Pearman } \\
\text { 2009). }\end{array}$ \\
\hline 12 & $\begin{array}{l}\text { Hydroelectric plant, } \\
\text { Spearfish Canyon, USA }\end{array}$ & $\begin{array}{l}\text { Ownership of a hydroelectric plant in South Dakota has been transferred from the } \\
\text { Homestake Mining Company to the City of Spearfish (Duex 2010). }\end{array}$ \\
\hline 13 & Ice rink, Essen, Germany & $\begin{array}{l}\text { A } 150 \text { m long ice rink has been established alongside coking ovens within the Zollverein } \\
\text { Colliery in Germany (Pearman 2009). }\end{array}$ \\
\hline 14 & $\begin{array}{l}\text { Design centre, Essen, } \\
\text { Germany }\end{array}$ & $\begin{array}{l}\text { The former boilerhouse at the Zollverein Colliery now houses a regional design centre } \\
\text { (Pearman 2009). }\end{array}$ \\
\hline 15 & $\begin{array}{l}\text { Walking path and } \\
\text { interpretive pathway, } \\
\text { Lead, USA }\end{array}$ & $\begin{array}{l}\text { The Homestake Mine's mill and refinery have been remediated and revegetated, with a } \\
\text { portion of the area developed as a walking path and interpretative pathway that includes } \\
\text { displays of mining equipment and methods along with historical information on the mine } \\
\text { and Lead history (Duex 2010). }\end{array}$ \\
\hline 16 & $\begin{array}{l}\text { Industriekultur, } \\
\text { Ruhrgebiet, Germany }\end{array}$ & $\begin{array}{l}\text { The Industrial Heritage Trail showcases gasometers, blast furnaces, mining towers and } \\
\text { other monuments (many of which are now theatres, art displays and recreational } \\
\text { facilities) linked by } 400 \mathrm{~km} \text { of roads, railway lines and waterways (Pearman 2009). }\end{array}$ \\
\hline \multicolumn{3}{|c|}{ Mining equipment and mine support infrastructure } \\
\hline 17 & $\begin{array}{l}\text { King Coal sculpture, } \\
\text { Durham, England }\end{array}$ & $\begin{array}{l}\text { The head of the King Cole sculpture was constructed from dismantled local industries } \\
\text { including colliery scrap metal (Pearman 2009). }\end{array}$ \\
\hline
\end{tabular}




\begin{tabular}{|c|c|c|}
\hline Uses & & Description \\
\hline 18 & $\begin{array}{l}\text { Desalination plant, } \\
\text { Witbank, South Africa }\end{array}$ & $\begin{array}{l}\text { A reverse osmosis water treatment plant used previously to treat polluted water from an } \\
\text { underground coal mine now supplies potable water to the local municipality (Pearman } \\
\text { 2009). }\end{array}$ \\
\hline 19 & $\begin{array}{l}\text { Big Pit National Coal } \\
\text { Museum, Blaenafon, } \\
\text { Wales }\end{array}$ & $\begin{array}{l}\text { The Big Pit National Coal Museum preserves Welsh coal mining heritage and can be } \\
\text { recognised by its distinctive red winding tower that provided access to and from the } \\
\text { mine. Exhibition spaces have been established in the mine's old baths (McNab 2018). }\end{array}$ \\
\hline 20 & $\begin{array}{l}\text { Industrial Heritage } \\
\text { Discovery Centre, } \\
\text { Cornwall, England }\end{array}$ & $\begin{array}{l}\text { An industrial heritage discovery centre established at the former East Pool Mine in the } \\
\text { Cornish Mining World Heritage Site showcases two Cornish beam engines (a pumping } \\
\text { engine and a winding engine) (www.nationaltrust.org.uk). }\end{array}$ \\
\hline 21 & $\begin{array}{l}\text { Killhope, The North of } \\
\text { England Lead Mining } \\
\text { Museum, Durham, } \\
\text { England }\end{array}$ & $\begin{array}{l}\text { One of the attractions at Killhope is the waterwheel installed in the late 19th century to } \\
\text { facilitate washing of lead ore and which has been restored to full working order (McNab } \\
\text { 2018). }\end{array}$ \\
\hline 22 & $\begin{array}{l}\text { Levant Mine and Beam } \\
\text { Engine, Pendeen, England }\end{array}$ & $\begin{array}{l}\text { Part of the Cornish Mining World Heritage Site, a restored 1940s beam engine is at the } \\
\text { heart of this tourist attraction (www.nationaltrust.org.uk). }\end{array}$ \\
\hline 23 & $\begin{array}{l}\text { National Coal Mining } \\
\text { Museum for England, } \\
\text { Wakefield, England }\end{array}$ & $\begin{array}{l}\text { The colliery buildings including the winding engine house and control room, baths and } \\
\text { stables can be explored at the former Caphouse Colliery (McNab 2018). }\end{array}$ \\
\hline 24 & $\begin{array}{l}\text { National Mining Museum, } \\
\text { Newtongrange, Scotland }\end{array}$ & $\begin{array}{l}\text { The National Mining Museum south of Edinburgh is based at the former Lady Victoria } \\
\text { Colliery and includes the most powerful winding engine in Scotland, the most extensive } \\
\text { preserved suite of Lancashire boilers in the UK and the only extant timber dredger in } \\
\text { Europe (National Mining Museum Scotland 2019). }\end{array}$ \\
\hline 25 & $\begin{array}{l}\text { Museum of Lead Mining, } \\
\text { Wanlockhead, Scotland }\end{array}$ & $\begin{array}{l}\text { Attractions at the Museum of Lead Mining include a beam engine and former miner } \\
\text { accommodation at the Straitsteps Cottages (McNab 2018). }\end{array}$ \\
\hline 26 & $\begin{array}{l}\text { Gwalia Museum, Gwalia, } \\
\text { Australia }\end{array}$ & $\begin{array}{l}\text { One of the main features of the Gwalia Museum at the former Sons of Gwalia gold mine is } \\
\text { the } 1912 \text { Fraser and Chalmers steam-operated winder. The old mine administration } \\
\text { buildings now house the Gwalia Museum's collection of documents, photographs and } \\
\text { objects, and the mine manager's house (Hoover House) is now a luxury bed and breakfast } \\
\text { and function centre (www.gwalia.org.au/). }\end{array}$ \\
\hline 27 & $\begin{array}{l}\text { Geevor Tin Mine Museum } \\
\text { and Heritage Centre, } \\
\text { Pendeen, England }\end{array}$ & $\begin{array}{l}\text { The Geevor Tin Mine ceased operation in the } 1990 \text { s and has been left like a time capsule } \\
\text { with workers' possessions, clothes and tools left as if they had just finished work (McNab } \\
\text { 2018). }\end{array}$ \\
\hline 28 & $\begin{array}{l}\text { Ferropolis concert venue, } \\
\text { Dessau, Germany }\end{array}$ & $\begin{array}{l}\text { A gigantic crane has been turned into a } 25,000 \text {-seat concert venue. Other structures at } \\
\text { the site include diggers and baggers. It is possible to abseil down one of the "sleeping } \\
\text { giants" at this site (Pearman 2009). }\end{array}$ \\
\hline 29 & Ski resort, Park City, USA & $\begin{array}{l}\text { Mining infrastructure has been adapted to form features in the skiing landscape at a Utah } \\
\text { ski resort that hosted some of the Winter Olympics in } 2002 \text { (Pearman 2009). }\end{array}$ \\
\hline 30 & $\begin{array}{l}\text { Wieliczka Salt Mine } \\
\text { Tourist Route, Poland }\end{array}$ & $\begin{array}{l}\text { Original tools and mining equipment remaining at the Wieliczka Salt Mine help visitors } \\
\text { understand the techniques used over the ages (Pearman 2009). }\end{array}$ \\
\hline \multicolumn{3}{|c|}{ Railways, tramways and associated infrastructure } \\
\hline 31 & $\begin{array}{l}\text { Mineral Tramways } \\
\text { Heritage Project, } \\
\text { Cornwall, England }\end{array}$ & $\begin{array}{l}\text { Many of the original mineral tramway routes that conveyed ore and fuel from Cornish } \\
\text { mines to ports have been converted to recreational trails (Pearman 2009). }\end{array}$ \\
\hline 32 & $\begin{array}{l}\text { Long-distance cycle path, } \\
\text { Durham, England }\end{array}$ & $\begin{array}{l}\text { An abandoned railway line near a former coal mine has been converted to a long-distance } \\
\text { cycle path (Pearman 2009). }\end{array}$ \\
\hline 33 & High Line, New York, USA & $\begin{array}{l}\text { More than } 2 \mathrm{~km} \text { of elevated linear park, greenway and rail trail have been created on a } \\
\text { former New York Central Railroad spur on the west side of Manhattan in New York, USA } \\
\text { (Hammond \& David 2011). }\end{array}$ \\
\hline 34 & $\begin{array}{l}\text { Shelby Farms Greenline, } \\
\text { Memphis, USA }\end{array}$ & $\begin{array}{l}\text { This } 10.8 \mathrm{~km} \text { trail in Tennessee, which is also known as the Memphis Greenline, traverses } \\
\text { the USA's largest urban parks (www.shelbyfarmsgreenline.org). }\end{array}$ \\
\hline
\end{tabular}




\begin{tabular}{|c|c|c|}
\hline Uses & & Description \\
\hline 35 & $\begin{array}{l}\text { Midtown Greenway, } \\
\text { Minneapolis, USA }\end{array}$ & $\begin{array}{l}\text { An } 8.8 \mathrm{~km} \text { trail in Minnesota was developed adjacent to a former railroad corridor to } \\
\text { provide connections between the suburbs, the trail (nature) and the business area of } \\
\text { town (Midtown Greenway Coalition 2019). }\end{array}$ \\
\hline 36 & $\begin{array}{l}\text { Reading Viaduct, } \\
\text { Pennsylvania, USA }\end{array}$ & $\begin{array}{l}\text { Also known as the Viaduct Greene, this facility is dedicated to the preservation and } \\
\text { remediation of the Reading Viaduct as a public open green space for the residents of, and } \\
\text { visitors to, the greater Philadelphia area (www.readingviaduct.org). }\end{array}$ \\
\hline 37 & $\begin{array}{l}\text { Cowichan Trails, British } \\
\text { Columbia, Canada }\end{array}$ & $\begin{array}{l}\text { This community greenway incorporates walking, cycling and equestrian trails and } \\
\text { encourages communities and visitors to understand the lifecycle of mine sites and } \\
\text { supporting infrastructure, and the way in which mining infrastructure can be repurposed } \\
\text { for community benefit (Backhouse 2012). }\end{array}$ \\
\hline 38 & $\begin{array}{l}\text { Promenade Plantée, } \\
\text { Paris, France }\end{array}$ & $\begin{array}{l}\text { Also known as the Coulée Verte, this elevated } 4.7 \mathrm{~km} \text { greenway was built on top of an old } \\
\text { Vincennes railway. Known as the most innovating green space in Paris, it is available to } \\
\text { pedestrians, cyclists and inline skaters (Entwisle 2019). }\end{array}$ \\
\hline 39 & $\begin{array}{l}\text { Adirondacks railbiking } \\
\text { path, New York, USA }\end{array}$ & $\begin{array}{l}\text { Tourists use specialised bikes mounted on railway tracks in the Adirondack Mountains to } \\
\text { visit areas where iron ore and titanium dioxide were mined previously (Anderson 2017). }\end{array}$ \\
\hline 40 & $\begin{array}{l}\text { Rhode Island railbiking } \\
\text { path, New England, USA }\end{array}$ & $\begin{array}{l}\text { Located on Rhode Island, this railbiking path comprises the Northern Ramble (a } 9.6 \mathrm{~km} \\
\text { path from Portsmouth to the Sakonnet River) and the Southern Circuit, which also covers } \\
9.6 \mathrm{~km} \text { (Batten 2018). }\end{array}$ \\
\hline 41 & $\begin{array}{l}\text { Catskills railbiking path, } \\
\text { New York, USA }\end{array}$ & $\begin{array}{l}\text { Railbiking is conducted along } 12.9 \mathrm{~km} \text { of the historic Ulster and Delaware Railroad (Batten } \\
\text { 2018). }\end{array}$ \\
\hline 42 & $\begin{array}{l}\text { Nevada railbiking path, } \\
\text { Boulder City, USA }\end{array}$ & $\begin{array}{l}\text { This railbiking path utilises the historic Nevada Southern railroad in Boulder City, Nevada } \\
\text { (www.railexplorers.net). }\end{array}$ \\
\hline 43 & $\begin{array}{l}\text { Flekkefjordbanen } \\
\text { railbiking path, } \\
\text { Flekkefjordbanen, } \\
\text { Norway }\end{array}$ & $\begin{array}{l}\text { Railbiking occurs on a railway that connects Flekkefjord to Sørlandsbanen in Norway. } \\
\text { Local residents are intent on preserving the railway and converting it into a living museum } \\
\text { (Batten 2018). }\end{array}$ \\
\hline 44 & $\begin{array}{l}\text { Kääntöpöytä, Helsinki, } \\
\text { Finland }\end{array}$ & $\begin{array}{l}\text { An abandoned train turntable has been rejuvenated as an organic food hub (Burnham } \\
\text { 2018). }\end{array}$ \\
\hline 45 & $\begin{array}{l}\text { Babylon (sculpture), } \\
\text { Cambridge, England }\end{array}$ & $\begin{array}{l}\text { Exhibited at Jesus College at the University of Cambridge, the sculpture Babylon was } \\
\text { created in the } 1970 \text { s by the British sculptor Sir Anthony Caro from used jarrah railway } \\
\text { sleepers (Jesus College 2019). }\end{array}$ \\
\hline 46 & $\begin{array}{l}\text { Railway Sleeper House, } \\
\text { Miyake Island, Japan }\end{array}$ & $\begin{array}{l}\text { Shin Takasuga's Railway Sleeper House was constructed from used hardwood railway } \\
\text { sleepers. It was constructed in } 1970 \text { as a retreat and a communal residential building } \\
\text { (Deplazes 2005). }\end{array}$ \\
\hline 47 & $\begin{array}{l}\text { Aizkibel Library extension, } \\
\text { Azkoitia, Spain }\end{array}$ & $\begin{array}{l}\text { Reclaimed railway sleepers were used to extend a Spanish library originally built at a } \\
\text { railway station. The use of sleepers references the site's history (Mairs 2015). }\end{array}$ \\
\hline 48 & $\begin{array}{l}\text { Kimball Arts Centre } \\
\text { extension, Park City, USA }\end{array}$ & $\begin{array}{l}\text { An extension of an art centre will be constructed from railway sleepers reclaimed from } \\
\text { the Great Salt Lake in Utah (Frearson 2012). }\end{array}$ \\
\hline 49 & $\begin{array}{l}\text { London County Hall } \\
\text { Garden, London, UK }\end{array}$ & $\begin{array}{l}\text { Used railway sleepers were used to create a border around a Japanese garden at London } \\
\text { County Hall, opposite the Houses of Parliament in London (Kilgraney Railway Sleepers } \\
\text { n.d.). }\end{array}$ \\
\hline 50 & Amphitheatre, Norway & $\begin{array}{l}\text { An amphitheatre and associated seating in Norway were constructed from used jarrah } \\
\text { railway sleepers (Kilgraney Railway Sleepers n.d.). }\end{array}$ \\
\hline 51 & Outdoor sculptures, USA & $\begin{array}{l}\text { Railway spikes, scrap metal and other items are used by Arizona-based artist John V } \\
\text { Wilhelm to create outdoor sculptures (Metal Men Recycling 2015). }\end{array}$ \\
\hline 52 & $\begin{array}{l}\text { Train test track, Asfordby, } \\
\text { UK }\end{array}$ & $\begin{array}{l}\text { A section of railway track previously utilised by the coal mine at Asfordby is now used a } \\
\text { test site for a range of equipment including trains (Pearman 2009). }\end{array}$ \\
\hline \multicolumn{3}{|c|}{ Locomotives and railway cars } \\
\hline 53 & $\begin{array}{l}\text { Redbird Reef, Delaware, } \\
\text { USA }\end{array}$ & $\begin{array}{l}\text { Old subway cars sunk off the Delaware coast form the basis for an artificial reef (Jochum } \\
\text { \& Witkop 2010). }\end{array}$ \\
\hline
\end{tabular}




\begin{tabular}{|c|c|c|}
\hline Uses & & Description \\
\hline 54 & Artificial reef, Sinai, Egypt & $\begin{array}{l}\text { An old locomotive has been sunk into the Red Sea to provide an artificial reef (Preuss } \\
\text { 2010). }\end{array}$ \\
\hline 55 & $\begin{array}{l}\text { Controversy Tram Hotel, } \\
\text { Amsterdam, Netherlands }\end{array}$ & $\begin{array}{l}\text { An old tram that used to run through Amsterdam and neighbouring cities has been } \\
\text { turned into a bed and breakfast (Preuss 2010). }\end{array}$ \\
\hline 56 & $\begin{array}{l}\text { Homeless shelters, } \\
\text { Beijing, China }\end{array}$ & $\begin{array}{l}\text { Ten DK-16 trains, each with six cars, have been converted into temporary winter shelters } \\
\text { for the homeless. These trains, which are located in Guanguyuan, can house } \\
\text { approximately 1,200 people (Chow 2008). }\end{array}$ \\
\hline 57 & $\begin{array}{l}\text { La Caverne aux Livres } \\
\text { book shop, Auvers-sur- } \\
\text { Oise, France }\end{array}$ & $\begin{array}{l}\text { The entrance to La Caverne aux Livres, a book shop located around } 30 \mathrm{~km} \text { north of Paris, } \\
\text { is housed in an old railway hanger from which visitors access an old postal train whose } \\
\text { cars have been converted to house giant bookshelves (Preuss 2010). }\end{array}$ \\
\hline 58 & $\begin{array}{l}\text { Museum and information } \\
\text { centre, Nevada, USA }\end{array}$ & $\begin{array}{l}\text { A railway car's length and its public nature mean that it is well suited to being used as a } \\
\text { museum and information centre (Preuss 2010). }\end{array}$ \\
\hline 59 & $\begin{array}{l}\text { Photo exhibition, Tokyo, } \\
\text { Japan }\end{array}$ & An old railway carriage in Japan houses an exhibition of photographs (Preuss 2010). \\
\hline 60 & $\begin{array}{l}\text { Aurora Express Hotel, } \\
\text { Fairbanks, USA }\end{array}$ & $\begin{array}{l}\text { The Aurora Express Hotel is a bed and breakfast made from Alaskan railway cars } \\
\text { renovated to reflect historical periods (www.fairbanksalaskabedandbreakfast.com). }\end{array}$ \\
\hline 61 & $\begin{array}{l}\text { Runaway Train Diner, } \\
\text { Brownwood, USA }\end{array}$ & A recycled railway carriage in Texas now houses the Runaway Train Diner (Preuss 2010). \\
\hline 62 & Hound Inn, Arlecdon, UK & $\begin{array}{l}\text { The Hound Inn in Arlecdon is housed in a railway car that once operated on Hampshire's } \\
\text { Watercress Line (Preuss 2010). }\end{array}$ \\
\hline 63 & $\begin{array}{l}\text { Oregon Electric Station } \\
\text { restaurant, Eugene, USA }\end{array}$ & $\begin{array}{l}\text { Retired trains and an old train station have been converted into an eatery in Oregon } \\
\text { (Preuss 2010). }\end{array}$ \\
\hline 64 & $\begin{array}{l}\text { The Train Wreck } \\
\text { houseboat, Sausalito, } \\
\text { USA }\end{array}$ & $\begin{array}{l}\text { This railway car was used on the San Francisco and Northern Pacific Railway from } 1889 \\
\text { and on the Northwestern Pacific Railroad since 1907. It was retired in } 1936 \text { and became } \\
\text { part of a duplex in California. In 1979, it was converted into a houseboat (Pasquini 2009). }\end{array}$ \\
\hline 65 & $\begin{array}{l}\text { Oden State Fish Hatchery, } \\
\text { Michigan, USA }\end{array}$ & $\begin{array}{l}\text { An old Wolverine railway car has been used as a major rearing facility for brown and } \\
\text { rainbow trout at the Oden State Fish Hatchery since 1921. It was previously used to } \\
\text { transport fish in the early days of the hatchery (Preuss 2010). }\end{array}$ \\
\hline 66 & Church, Russia & $\begin{array}{l}\text { Recycled train compartments are being used as churches in Russia, with benches } \\
\text { provided by the railway authorities (Preuss 2010). }\end{array}$ \\
\hline 67 & $\begin{array}{l}\text { Training facility, } \\
\text { Greenville, USA }\end{array}$ & $\begin{array}{l}\text { An old boy scout's train in Carolina is now used as a training facility that also contains a } \\
\text { dining area (Preuss 2010). }\end{array}$ \\
\hline 68 & $\begin{array}{l}\text { Village Underground, East } \\
\text { London, UK }\end{array}$ & $\begin{array}{l}\text { The Village Underground was started in } 2006 \text { to develop affordable studios for creative } \\
\text { people who were struggling to become established in London. Retired Tube carriages } \\
\text { have been stacked onto old shipping containers and converted into co-working spaces. } \\
\text { This creative cultural hub hosts live art, concerts, theatre, exhibitions, club nights and } \\
\text { other performances (www.villageunderground.co.uk). }\end{array}$ \\
\hline 69 & $\begin{array}{l}\text { Wagon } 537 \text { Café and } \\
\text { Goods Shed Markets, } \\
\text { Collie, Australia }\end{array}$ & $\begin{array}{l}\text { Markets are held in the heritage-listed Old Goods Shed, which is a former railway station, } \\
\text { and a pop-up café is located in a former rail wagon (www.collierivervalley.com.au). }\end{array}$ \\
\hline \multicolumn{3}{|c|}{ Accommodation camps, workshops and offices } \\
\hline 70 & $\begin{array}{l}\text { Training and conference } \\
\text { venue, Katanga, } \\
\text { Democratic Republic of } \\
\text { Congo }\end{array}$ & $\begin{array}{l}\text { Former accommodation facilities present an opportunity for re-use as a training and } \\
\text { conference venue (Limpitlaw \& Briel 2014). }\end{array}$ \\
\hline 71 & $\begin{array}{l}\text { Town development node, } \\
\text { Congo-Brazzaville, } \\
\text { Democratic Republic of } \\
\text { Congo }\end{array}$ & $\begin{array}{l}\text { The proponent of a potash project decided to locate processing and staff facilities closer } \\
\text { to an existing town that would act as a natural node of development (Limpitlaw \& Briel } \\
\text { 2014). }\end{array}$ \\
\hline
\end{tabular}




\begin{tabular}{|c|c|c|}
\hline \multicolumn{2}{|c|}{ Uses } & \multirow{2}{*}{$\begin{array}{l}\text { Description } \\
\text { The San Martin mine's accommodation camp, maintenance shop and administration } \\
\text { offices were converted into an eco-hotel to attract people who enjoy nature and to } \\
\text { educate the public about the site's mining history (Roldan \& Purvance 2011). }\end{array}$} \\
\hline 72 & Eco-hotel, Honduras & \\
\hline 73 & $\begin{array}{l}\text { Clubrooms, Tom Price, } \\
\text { Australia }\end{array}$ & $\begin{array}{l}\text { Demountable buildings no longer in use at the Tom Price iron ore mine were repurposed } \\
\text { as clubrooms at the Tom Price Horse and Pony Club. }\end{array}$ \\
\hline 74 & $\begin{array}{l}\text { Las Ruinas de Huanchaca, } \\
\text { Chile }\end{array}$ & $\begin{array}{l}\text { The Ruins of Huanchaca comprise the remnants of an enormous silver smelting plant that } \\
\text { operated from } 1892 \text { to } 1902 \text { and are now a popular tourist attraction (Pearman 2009). }\end{array}$ \\
\hline 75 & $\begin{array}{l}\text { Educational and cultural } \\
\text { facilities, East Kalimantan, } \\
\text { Indonesia }\end{array}$ & $\begin{array}{l}\text { During community engagement, it was agreed that camp buildings at the Kelian mine } \\
\text { would be dismantled and donated to the local government for use by the community } \\
\text { (McGuire 2003). }\end{array}$ \\
\hline 76 & $\begin{array}{l}\text { Community facilities, } \\
\text { Murdochville, Canada }\end{array}$ & $\begin{array}{l}\text { Buildings from the Gaspe mine were donated to the town of Murdochville, and an } \\
\text { industrial park was created for the town as part of the mine's closure program (Gauthier } \\
\text { 2013). }\end{array}$ \\
\hline 77 & $\begin{array}{l}\text { Potosi Mining City, } \\
\text { Potosi, Bolivia }\end{array}$ & $\begin{array}{l}\text { Potosi's industrial heritage (including the system of aqueducts and artificial lakes that } \\
\text { supplied the hydraulic mills for grinding ore) is still visible three centuries after the main } \\
\text { mining activities ceased. This city was granted World Heritage Site status in } 1987 \\
\text { (Pearman 2009). }\end{array}$ \\
\hline 78 & $\begin{array}{l}\text { Sewell Mining Town, } \\
\text { Sewell, Chile }\end{array}$ & $\begin{array}{l}\text { An abandoned mining town, Sewell was declared a National Monument by the Chilean } \\
\text { government in } 1998 \text { and was classified as a World Heritage Site in } 2006 \text { (Pearman 2009). }\end{array}$ \\
\hline \multicolumn{3}{|c|}{ Trucks and buses } \\
\hline 79 & $\begin{array}{l}\text { Dump truck swimming } \\
\text { pool }\end{array}$ & A former dump truck was repurposed as a swimming pool (Buzznick n.d.). \\
\hline 80 & $\begin{array}{l}\text { Mobile hygiene stations, } \\
\text { San Francisco, USA }\end{array}$ & $\begin{array}{l}\text { Buses have been converted to become mobile sanitation services for the homeless } \\
\text { (Burnham 2018). }\end{array}$ \\
\hline 81 & $\begin{array}{l}\text { Homeless shelters, } \\
\text { Honolulu, USA }\end{array}$ & $\begin{array}{l}\text { Disused buses have been converted into homeless shelters and service units in Hawaii } \\
\text { (Burnham 2018). }\end{array}$ \\
\hline \multicolumn{3}{|c|}{ Equipment and materials } \\
\hline 82 & Artificial reef, USA & $\begin{array}{l}\text { The Rigs to Reefs program repurposes decommissioned oil rigs as artificial reefs to } \\
\text { provide fish habitat. A single rig can provide up to three acres of habitat (Recfishwest } \\
\text { 2017). }\end{array}$ \\
\hline 83 & $\begin{array}{l}\text { Artificial reef, Parker } \\
\text { Point, Western Australia }\end{array}$ & $\begin{array}{l}\text { Over } 10,000 \text { tonnes of reconstituted concrete from conveyor foundations and boulders } \\
\text { from a decommissioned seawall were used to construct the artificial reef (Zhou 2018). }\end{array}$ \\
\hline 84 & $\begin{array}{l}\text { Mining equipment, } \\
\text { Cornwall, UK }\end{array}$ & $\begin{array}{l}\text { Equipment from the soon-to-be abandoned Poldice copper mine was sold to other } \\
\text { workings (Morris 2016). }\end{array}$ \\
\hline 85 & $\begin{array}{l}\text { Livestock feed mixer, } \\
\text { Perth, Australia }\end{array}$ & $\begin{array}{l}\text { An old concrete mixer from a Pilbara exploration camp was repurposed as a machine to } \\
\text { mix batches of livestock feed. }\end{array}$ \\
\hline 86 & $\begin{array}{l}\text { Nonslip flooring for } \\
\text { livestock, Denver, USA }\end{array}$ & $\begin{array}{l}\text { Rubber tracks removed from bulldozers are used as nonslip flooring for livestock (Spiegel } \\
\text { 2013). }\end{array}$ \\
\hline 87 & $\begin{array}{l}\text { Livestock stall mats and } \\
\text { lining }\end{array}$ & $\begin{array}{l}\text { Used conveyor belts can be repurposed as horse stall mats, cattle stall mats, barn aisle } \\
\text { matting and sheep/pig pen lining. They can also be used as hitching post matting (Atlas } \\
\text { Belting n.d.). }\end{array}$ \\
\hline 88 & $\begin{array}{l}\text { Livestock fencing, Kansas, } \\
\text { USA }\end{array}$ & Old pipelines are being used as fences in central Kansas (Spiegel 2013). \\
\hline 89 & $\begin{array}{l}\text { Cattle windbreaks and } \\
\text { culvert barriers }\end{array}$ & $\begin{array}{l}\text { Used conveyor belts can be repurposed as cattle windbreaks and as barriers to prevent } \\
\text { livestock from entering culverts (Atlas Belting n.d.). }\end{array}$ \\
\hline 90 & Livestock feeders & Tyres from mine sites are being repurposed as feeders for livestock (Spiegel 2013). \\
\hline 91 & $\begin{array}{l}\text { Steel coil pads and mats, } \\
\text { and other industrial } \\
\text { purposes }\end{array}$ & $\begin{array}{l}\text { Used conveyor belts can be repurposed for a range of industrial purposes including steel } \\
\text { coil pads and mats, construction mats, gaskets and die-cut products, and rubber lining for } \\
\text { sandblasting rooms (Atlas Belting n.d.). }\end{array}$ \\
\hline
\end{tabular}




\begin{tabular}{|c|c|c|}
\hline \multicolumn{2}{|c|}{ Uses } & \multirow{2}{*}{$\begin{array}{l}\text { Description } \\
\text { Used conveyor belts can be repurposed as trailer and truck bed liners, custom mud flaps, } \\
\text { anti-fatigue and vibration floor mats, shipping mats, etc. (Atlas Belting n.d.). }\end{array}$} \\
\hline 92 & $\begin{array}{l}\text { Protective covers and } \\
\text { matting }\end{array}$ & \\
\hline 93 & Snow plough blades & $\begin{array}{l}\text { Blades, guards and shields for snow ploughs can be constructed from used conveyor belts } \\
\text { (Atlas Belting n.d.). }\end{array}$ \\
\hline 94 & Dock bumpers & $\begin{array}{l}\text { Recycled conveyor belting can be used to line docks to protect both boats and docks } \\
\text { (Atlas Belting n.d.). }\end{array}$ \\
\hline 95 & Landscape edging & $\begin{array}{l}\text { Narrow strips of used conveyor belting can be used as garden edging to prevent grass and } \\
\text { weeds from encroaching (Atlas Belting n.d.). }\end{array}$ \\
\hline \multicolumn{3}{|c|}{ Other infrastructure } \\
\hline 96 & $\begin{array}{l}\text { Grünerløkka Studenthus, } \\
\text { Oslo, Norway }\end{array}$ & $\begin{array}{l}\text { A grain silo has been converted to become a 226-unit student housing complex (Burnham } \\
\text { 2018). }\end{array}$ \\
\hline 97 & $\begin{array}{l}\text { Premier Mill Hotel, } \\
\text { Katanning, Australia }\end{array}$ & $\begin{array}{l}\text { An old flour mill has been converted into an award-winning boutique hotel and café } \\
\text { (Adysti 2019; Anon 2019b). }\end{array}$ \\
\hline 98 & $\begin{array}{l}\text { Community and gathering } \\
\text { space, Providence, USA }\end{array}$ & $\begin{array}{l}\text { Cranes, rough brick and metal buildings at a steel yard on the Woonasquatucket River, } \\
\text { Rhode Island, now feature at a community and gathering space for the arts (Barber 2017). }\end{array}$ \\
\hline 99 & $\begin{array}{l}\text { The Green Building, } \\
\text { Louisville, USA }\end{array}$ & $\begin{array}{l}\text { A } 115 \text {-year-old former dry goods store in Kentucky has been converted into a mixed-use } \\
\text { commercial building with a gallery, offices, conference room and an event space (Barber } \\
\text { 2017). }\end{array}$ \\
\hline 100 & $\begin{array}{l}\text { Horse stables, Perth, } \\
\text { Australia }\end{array}$ & $\begin{array}{l}\text { Steel pillars salvaged during the demolition of the Parker Point pellet plant in Dampier } \\
\text { were transported to Perth and used as the main structural supports for horse stables. }\end{array}$ \\
\hline 101 & $\begin{array}{l}\text { Horse training yard, Tom } \\
\text { Price, Australia }\end{array}$ & $\begin{array}{l}\text { Used conveyor belting from the Tom Price iron ore mine was used to line the rails } \\
\text { surrounding a training yard at the Tom Price Horse and Pony Club. }\end{array}$ \\
\hline
\end{tabular}

\section{References}

Adysti, S 2019, Mill Wins Big, viewed 4 April 2019 https://thewest.com.au/news/albany-advertiser/mill-wins-big-ng-b881154797z Anderson, E 2017, Pedalling the rails debuts along Adirondack mining route, viewed 5 February 2019, https://www.stamfordadvocate.com/7day-business/article/Pedaling-the-rails-debuts-along-Adirondack-mining-11297625.php

Anon 2014, AngloGold Ashanti and mine site infrastructure, viewed 1 March 2019, https://www.miningglobal.com/miningsites/anglogold-ashanti-and-mine-site-infrastructure

Anon 2018, History of the Slime Plant, viewed 22 March 2019, https://www.deadwoodmountaingrand.com/home/history/64history-of-the-slime-plant.html

Anon 2019a, History of the Real Deadwood, viewed 22 March 2019, https://www.deadwood.com/history/

Anon 2019b, Premier Mill Hotel, viewed 21 March 2019, https://premiermillhotel.com/\#\#home

Atlas Belting n.d., Recycled Conveyor Belt Products, viewed 6 March 2019, https://www.atlasbelt.com/recycled-conveyor-beltproducts.php

Backhouse, DC 2012, 'Community greenways - ecological and recreational re-use of industrial landscapes', in AB Fourie \& $\mathrm{M}$ Tibbett (eds), Proceedings of the Seventh International Conference on Mine Closure, Australian Centre for Geomechanics, Perth, pp. 759-770.

Bainton, N \& Holcombe, S 2018, The Social Aspects of Mine Closure: A Global Literature Review, Centre for Social Responsibility in Mining, Sustainable Minerals Institute, Brisbane.

Barber, M 2017, 9 projects that reimagine old buildings, from factories to firehouses, viewed 18 January 2019, https://www.curbed.com/2017/11/2/16598172/adaptive-reuse-architecture-united-states

Batten, C 2018, The Best Railbike Tours and Where to Find Them, viewed 5 February 2019, https://www.themanual.com/outdoors/ best-rail-bike-tours/

Bureau of Safety and Environmental Enforcement n.d., Rigs to Reefs, viewed 5 June 2019, https://www.bsee.gov/what-wedo/environmental-focuses/rigs-to-reefs

Burnham, S 2018, Reprogramming the City: Doing More with What We Have, viewed 21 March 2019, https://reprogrammingthecity.com/

Buzznick n.d., These DIY Pools will Leave You Laughing, but still a Little Envious, viewed 21 March 2019, https://www.buzznick.com/diy-pools/

Chaloping-March, M 2008, 'Business Expediency, Contingency and Socio-Political realities - a Case of Unplanned Mine Closure', in A Fourie, M Tibbett, I Weiersbye \& P Dye (eds), Proceedings of the Third International Seminar on Mine Closure, Australian Centre for Geomechanics, Perth, pp. 863-872. 
Chow, E 2008, Old Beijing Subway Trains Get Second Life as Homeless Shelters, viewed 21 March 2019, https://gizmodo.com/oldbeijing-subway-trains-get-second-life-as-homeless-s-5100683?IR=T

Corner, J 1997, 'Ecology and landscape as agents of creativity', in GF Thompson, F Steiner \& R Frederick (eds), Ecological Design and Planning, John Wiley \& Sons, New York.

Department of Jobs, Tourism, Science and Innovation n.d., What is a State Agreement, viewed 3 March 2019, https://www.jtsi.wa.gov.au/what-we-do/manage-state-agreements/what-is-a-state-agreement

Department of Mines and Petroleum and Environmental Protection Authority 2015, Guidelines for Preparing Mine Closure Plans, Government of Western Australia, Perth, $96 \mathrm{p}$.

Deplazes, A (ed) 2005, Constructing Architecture: Materials Processes Structures - A Handbook, Birkhauser, Basel.

Duex, TA 2010, 'Sustainable Development Activities during Closure of the Homestake Gold Mine', in A Fourie, M Tibbett \& J Wiertz (eds), Proceedings of the Fifth International Seminar on Mine Closure, Australian Centre for Geomechanics, Perth, pp. 193-198.

Entwisle, T 2019, Plant Promenade in Paris, viewed 17 April 2019, https://gardentravelhub.com/promenading-high-among-theplants-in-paris/

Environment Protection Authority 2010, Site Contamination Information Sheet, Environment Protection Authority, Adelaide, 8 p.

Finucane, SJ 2016, 'Strategic Partnerships for Closure - business case, characteristics and life cycle', presentation provided at the Seeking Shared Value through Stakeholder Engagement and Partnerships for Mine Closure Workshop, Perth, 18 March 2016.

Francis, R \& Salveson, P n.d., Community Stations: Innovative Community Uses for Railway Stations and Land, Rail Delivery Group, Scotland.

Frearson, A 2012, The Kimball Art Centre by BIG, viewed 4 March 2019, https://www.dezeen.com/2012/02/14/the-kimball-artcentre-by-big/

Gauthier, C 2013 Gaspe Mines Closure: A Success Story in Mine Reclamation, paper presented at CleanUp 2013, Melbourne.

Government of South Australia 1993, Environment Protection Act 1993, Australia.

Government of Western Australia 2016, Land Administration Amendment Bill 2016, Australia.

Government of Western Australia 2003, Contaminated Sites Act 2003, Australia.

Government of Western Australia 1997, Land Administration Act 1997, Australia.

Hammond, R \& David, J 2011, High Line: The Inside Story of New York City's Park in the Sky, FSG Originals.

Harvey, BE 2016, 'The eye of the beholder - utility and beauty in mine closure', in AB Fourie \& M Tibbett (eds), Proceedings of the 11th International Seminar on Mine Closure, Australian Centre for Geomechanics, Perth, pp. 17-23.

Jesus College 2019, Anthony Caro, viewed 22 March 2019, https://www.jesus.cam.ac.uk/college/events/sculptureclose/2009/anthony-caro

Jochum, K \& Witkop, N 2010, Old Subway Cars become Artificial Reefs, viewed 21 March 2019, https://www.dw.com/en/oldsubway-cars-become-artificial-reefs/a-5544740

Kilgraney Railway Sleepers n.d., Public Projects Using Railway Sleepers, viewed 7 March 2019, http://www.railwaysleepers.com/projects/buildings-using-railway-sleepers

Kivinen, S 2017, 'Sustainable post-mining land use: are closed metal mines abandoned or re-used space?', Sustainability, vol. 9 , pp. 1-18.

Lee, C \& Chen, K 2016, 'Exploring factors determining the attractiveness of railway tourism', Journal of Travel \& Tourism Marketing, vol. 34, no. 4, pp. 461-474.

Limpitlaw, D \& Briel, A 2014, 'Post-mining land use opportunities in developing countries - a review', The Journal of The Southern African Institute of Mining and Metallurgy, vol. 114, pp. 899-903.

Loures, L \& Panagopoulos, T 2007, 'Sustainable reclamation of industrial areas in urban landscapes', WIT Transactions on ecology and the Environment, vol. 102, pp. 791-800.

Lowry, P 2001, Finding beauty and meaning in a post-industrial landscape, viewed 16 April 2019, http://www.postgazette.com/magazine/20010226lowry4.asp

Macaulay, R 1953, The Pleasure of Ruins, Walker and Company, New York.

Mairs, J 2015, Estudio Beldarrain uses reclaimed railway sleepers to extend Spanish library, viewed 4 April 2019 , https://www.dezeen.com/2015/11/26/aizkibel-library-extension-reclaimed-railway-sleepers-spain-estudio-beldarrain/

McCandless, C 2013, No Longer Just a Hole in the Ground. The Adaptive Reuse of Resource Depleted Quarries, viewed 28 March 2019, http://www.mit.edu/people/spirn/Public/Ulises-11-308/Quarrying.pdf

McGuire, G 2003, 'Managing Mine Closure Risks in Developing Communities - a Case Study, Kelian Equatorial Mining, Indonesia', in Mining Risk Management Conference, Australasian Institute of Mining and Metallurgy, Carlton, pp. 1-10.

McNab, K 2018, Britain's Best Places to See: Mines and Mining Museums, viewed 21 March 2019, https://museumcrush.org/ britains-best-places-to-see-mines-and-mining-museums/

Metal Men Recycling 2015, 4 Artists who Work with Scrap Metal, viewed 6 April 2019, https://www.metalmenrecycling.com.au/blog/4-artists-who-work-with-scrap-metal/

Midtown Greenway Coalition 2019, About the Greenway, viewed 2 March 2019, http://midtowngreenway.org/about-thegreenway/

Morris, M 2016, 10 Abandoned Copper \& Tin Mines of Cornwall, viewed 21 March 2019, https://www.urbanghostsmedia.com/ 2016/12/abandoned-tin-mines-cornwall/

Moulis Legal 2015, Contaminated Land in Western Australia, Moulis Legal, Milton, $4 \mathrm{p}$.

Murphy, D 2016, Mine Closure - are we using the right drivers?, Australasian Institute of Mining and Metallurgy Bulletin, viewed 31 May 2019, https://www.ausimmbulletin.com/feature/mine-closure-are-we-using-the-right-drivers/ 
National Mining Museum Scotland 2019, National Mining Museum Scotland, viewed 21 March 2019, https://nationalminingmuseum.com/the-colliery/

Parshley, JV \& MacCallum, CS 2016, 'Attractive nuisances and wicked solutions', in AB Fourie \& M Tibbett (eds), Proceedings of the 11th International Conference on Mine Closure, Australian Centre for Geomechanics, Perth, pp. 229-240.

Pasquini, P 2009, Sausalito, California: Railroad Car House Boat, viewed 21 March 2019, https://www.roadsideamerica.com/ tip/23151

Pearman, G 2009, 101 Things to do with a Hole in the Ground, Post-Mining Alliance and the Eden Project, Bodelva, St Austell, Cornwall.

Pilbara Development Commission n.d., Economic Infrastructure, viewed 7 June 2019, https://www.pdc.wa.gov.au/ourfocus/strategicinitiatives/economic-infrastructure

Preuss, S 2010, Ten Repurposed Railroad Cars, viewed 21 March 2019, https://recyclenation.com/2010/11/repurposed-recyclingrailroa-cars/

Rademeyer, B \& Le Roux, T 2008, 'Mine infrastructure planning and design for closure - integrating sustainable post-closure land use from the outset into the design of mine infrastructure', in AB Fourie, M Tibbett, IM Weiersbye \& PJ Dye (eds), Proceedings of the Third International Seminar on Mine Closure, Australian Centre for Geomechanics, Perth, pp. 255-267.

Recfishwest 2017, Artificial Reefs in Australia: A Guide to Developing Aquatic Habitat Enhancement Structures, viewed 5 June 2019. https://recfishwest.org.au/wp-content/uploads/2015/08/Artificial-Reefs-in-Australia.pdf

Roldan, CF \& Purvance, D 2011, 'San Martin mine in Honduras - from closure to sustainability', in A Fourie, M Tibbett \& A Beersing (eds), Proceedings of the Sixth International Seminar on Mine Closure, Australian Centre for Geomechanics, Perth, pp. 461-470.

Spiegel, B 2013, Repurposing Goes Mainstream, viewed 21 March 2019, https://www.agriculture.com/news/business/repurposinggoes-mainstream_5-ar31607

The Partnering Initiative 2019, The Benefits and Risks of Partnering, viewed 12 June 2019, https://thepartneringinitiative.org/about-us/philosophy-and-approach/the-benefits-and-risks-of-partnering/

Townsend, AR 1992, 'The attractions of urban areas', Tourism Recreation Research, vol. 17, no. 2, pp. 24-32.

Zhou, V 2018, Rio Tinto recreates life on coral reef in Western Australia, viewed 5 June 2019, https://www.australianmining.com.au/features/rio-tinto-recreates-life-coral-reefs/ 
